\title{
Variables at the Community Health Center Have the Ecological Effect on the Performance of Health Workers: A Multilevel Evidence from Klaten, Central Java
}

\author{
Nia Handayani' ${ }^{1)}$, Didik Gunawan Tamtomo²), Bhisma Murti' \\ ${ }^{1)}$ Masters Program in Public Health, Universitas Sebelas Maret \\ 2)Faculty of Medicine, Universitas Sebelas Maret
}

\section{ABSTRACT}

Background: Performance is a work achievement that can be achieved from a job. Employee performance in an organization leads to the ability of employees to complete all tasks that have become their responsibility. Various problems in the workplace can often cause work stress, if it lasts long can cause various disturbances. Success in achieving goals is supported by the role of a leader with the leadership style used. This study aimed to examine the effects of work stress and leadership style on the performance of public health workers.

Subjects and Method: This was a cross sectional study conducted at the Klaten District Health Center, Central Java, from November to December, 2019. A sample of 200 health workers was selected by stratified random sampling. The dependent variable was work performance. The independent variables were work stress, leadership style, education, tenure, and type of work. The data were collected by questionnaire and analyzed by a multilevel logistic regression run on Stata 13.

Results: Performance of health workers decreased with heavy work stress $(b=-1.65 ; 95 \% \mathrm{CI}=-$ 2.58 to $-0.72 ; p=0.001)$. Performance of health workers increased with democratic leadership style $(b=1.40 ; 95 \% \mathrm{CI}=0.44$ to $2.36 ; \mathrm{p}=0.004)$, high education level $(b=1.58 ; 95 \% \mathrm{CI}=0.65$ to 2.52; $p=0.001)$, tenure $\geq 6$ years $(b=1.72 ; 95 \%$ $\mathrm{CI}=0.73$ to $2.70 ; \mathrm{p}=0.001$ ), and type of work without any additions $(\mathrm{b}=2.05 ; 95 \% \mathrm{CI}=1.07$ to 3.03; $\mathrm{p}<0.001$ ). Community health center had ecological effect on performance of health workers with ICC $=12.74 \%$.

Conclusion: Performance of health workers decreases with heavy work stress. Performance of health workers increases with democratic leadership style, high education level, tenure $\geq 6$ years, and type of work without any additions. Community health center has ecological effect on performance of health workers.

Keywords: work performance, work stress, leadership style, community health center

\section{Correspondence:}

Nia Handayani. Masters Program in Public Health, Universitas Sebelas Maret. Jl. Ir. Sutami 36A, Surakarta 57126, Central Java. Email: niahandayani19@gmail.com. Mobile: +6282133055176.

\section{Cite this as:}

Handayani N, Tamtomo DG, Murti B (2020). Variables at the Community Health Center Have the Ecological Effect on the Performance of Health Workers: A Multilevel Evidence from Klaten, Central Java. J Health Policy Manage. 05(02): 152-161. https://doi.org/10.26911/thejhpm.2020.05.02.08

cc (i) (2) Journal of Health Policy and Management is licensed under a Creative Commons Attribution-NonCommercial-ShareAlike 4.o International License.

\section{BACKGROUND}

The organization is a group of people who work together to achieve the goals that have been determined together (Busro and $\mathrm{Mu}-$ hammad, 2018). The process of achieving goals within an organization, there are various important components to help achieve goals. Among these components quality human resources can determine the success of an organization in achieving its goals.

Regulation of the Minister of Health of the Republic of Indonesia Number 75 of 2014 concerning Public health center states that Public health center as one type of first-level 
Handayani et al./ Ecological effect of community health center on the work performance

health service facility has an important role in the national health system, particularly the health effort subsystem. Adequate resources for public health center are needed according to the type, number and function and competence according to standards. To support their duties, the health centers have health personnel who have the authority and skills in accordance with their fields of expertise (Mawaranti and Prasetio, 2018).

Success in achieving the goals of an organization is supported by the role of a leader with a leadership style in influencing employees. Leadership style basically has the understanding as an embodiment of a leader behavior regarding his ability to lead (Samsuddin, 2018). Leadership style in an organization can affect motivation and job satisfaction among employees (Musinguzi, 2018).

According to Li et al. (2017) the higher the imbalance between individual abilities and outside demands, the higher the stress level experienced. Stress is not always a bad impact, but it can also have a positive impact on the individual because it can encourage individuals to excel (Wahyudi, 2017). Stress at work can be experienced when there is an imbalance between work requests and the ability to manage them. Job stress is one of the things that causes employee performance in an organization to decline (Shivendra and Kumar, 2016). Job stress appears to arise when someone tries to manage responsibilities, tasks, or other forms of pressure related to work that he receives (Bhui et al., 2016).

Stress can be a positive indication for an individual to achieve, but excessive stress can reduce a person's productivity quickly. Stress is divided into two namely eustress (good stress) and distress (negative/bad stress). Excessive stress is certainly not good for health, but too little is also not ideal.

Performance is a work achievement that can be achieved from a job. According to Amir et al. (2018) leadership, compensation, and work discipline are 3 factors that influence employee performance. A leader has a duty to plan, inform, make, and evaluate various decisions that will be made by all employees to achieve a goal. This study aims to look at the effect of work stress and leadership style on the performance of public health center staff.

\section{SUBJECTS AND METHOD}

\section{Study Design}

This was an analytic observational study with a cross sectional design. The study was conducted at the Klaten District Health Center, Central Java, from November to December, 2019.

\section{Population and Sample}

A sample of 200 health workers consisting of 5 health personnel and 3 non-health personnel from each public health center in Klaten District was selected by stratified random sampling.

\section{Study Variables}

The dependent variable was work performance. The independent variables were work stress, leadership style, education, tenure, and type of work.

\section{Operational Definition of Variables} Employee performance was the result of work achieved by a person or group in accordance with the responsibilities of each employee. The data were collected by questionnaire. The measurement scale was continuous, and converted into dichotomous, coded $\mathrm{o}=$ poor performance and $1=$ good performance.

Work stress was an imbalance between the characteristics of work aspects and can occur in all conditions of work. The data were collected by questionnaire. The measurement scale was continuous, and converted into dichotomous, coded $\mathrm{O}=$ mild stress $($ score $<20)$ and $1=$ severe stress (score $\geq 20$ ).

Leadership style was a way used by a leader in interacting to influence, direct, 
Handayani et al./ Ecological effect of community health center on the work performance

encourage, and control other people or subordinates to achieve a goal. The data were collected by questionnaire. The measurement scale was continuous, and converted into dichotomous, coded $\mathrm{O}=$ authoritarian (score $<24$ ) and $1=$ democratic (score $\geq 24$ ).

Education level was the level of ability of a person in a school based on the last diploma he has. The data were collected by questionnaire. The measurement scale was continuous, and converted into dichotomous, coded $\mathrm{O}=<$ Diploma III and $1=\geq$ Diploma III .

Tenure was the length of time a person works in an institution from the first time he entered until now. The data were collected by questionnaire. The measurement scale was continuous, and converted into dichotomous, coded $0=<6$ years and $1=\geq 6$ years.

Type of Work was the main activity carried out by study subjects and earns income from these activities both medical and non-medical. The measuring instrument used was a questionnaire. The scale of the data is continuous, and converted into a dichotomy with the criteria $\mathrm{O}=$ additional work, $1=$ no additional work.

\section{Data Analysis}

Univariate analysis is used to describe each dependent and independent variable. Data is grouped according to data types and entered in the frequency distribution table. Bivariate analysis is used to determine the effect of independent and dependent variables by performing a chi-square test. Multivariate analysis explains the effect of work stress, leadership style, education, tenure, and type of work, on employee performance analyzed by multilevel logistic regression. Univariate, bivariate, and multivariate analyzes were performed using the Stata 13 program.

\section{Research Ethic}

This study was conducted after obtaining permission from the research ethics commission Dr. Moewardi Hospital, Surakarta, Central Java, Number: 1,155/X/HREC/ 2019. Research ethics includes consent sheets, anonymity, confidentiality, and ethical eligibility.

\section{RESULTS}

\section{Sample Characteristics}

Characteristics of the study subjects were identified based on employee age, main occupational type, level of education, and tenure.

Table 1. Sample characteristics

\begin{tabular}{llll}
\hline Variable & Criteria & n & \% \\
\hline Age & $<25$ years & 29 & 14.50 \\
& 25-35 years & 112 & 56.00 \\
& $35-45$ years & 53 & 26.50 \\
Occupation & $\geq 45$ years & 6 & 3.00 \\
\multirow{5}{*}{ Educational Background } & 125 & 62.50 \\
& Health personnel & 75 & 37.50 \\
& Non health personnel & 16 & 8.00 \\
& Senior high school & 88 & 44.00 \\
& Diploma III & 87 & 43.50 \\
& Bachelor & 9 & 4.50 \\
& Masters & 59 & 29.50 \\
& $<6$ years & 141 & 70.50 \\
\hline
\end{tabular}

Table 1 showed the majority of subjects aged 25-35 years were 112 people (56.00\%). The main types of work are as medical workers as many as 125 people $(62.50 \%)$ and non-medical as many as 75 people (37.50\%). The last education most of the study subjects were Diploma III as many as 88 people (44.00\%). The most tenure are employees 
Handayani et al./ Ecological effect of community health center on the work performance

who work $\geq 6$ years as many as 141 people (70.50\%).

\section{Univariate Analysis}

Based on Table 2 shows that work stress had mean $=19.04$ with the lowest score was 11 . Leadership style had mean $=23.93$ with the lowest score was 13. Work performance had 27.53 with the lowest score 16 .

Table 2. Univariate analysis (continuous data)

\begin{tabular}{lllllll}
\hline No. & Variable & n & Mean & SD & Min. & Max. \\
\hline 1. & Work Stress & 200 & 19.04 & 4.21 & 11 & 31 \\
2. & Leadership Style & 200 & 23.93 & 4.66 & 13 & 30 \\
3. & Employee Performance & 200 & 27.53 & 5.39 & 16 & 38 \\
\hline
\end{tabular}

Table 3 shows univariate analysis data (dichotomous data) on 200 study subjects which showed that the majority of study subjects experienced mild stress of 115 people (57.50\%) and 85 people (42.50\%) experien- ced severe stress. The leadership style perceived by most of the study subjects using the democratic leadership style of 135 people (67.50\%) and 65 people (32.50\%) rated the authoritarian leadership style.

Table 3. Univariate analysis (dichotomous data)

\begin{tabular}{llcc}
\hline Variable & Criteria & Frequency (n) & Percentage (\%) \\
\hline Work Stress & Mild & 115 & 57.50 \\
\multirow{2}{*}{ Leadership Style } & Severe & 85 & 42.50 \\
& Authoritarian & 65 & 32.50 \\
\multirow{5}{*}{ Education } & Democratic & 135 & 67.50 \\
& Senior high school and & 104 & 52.00 \\
Period of working & Diploma III & & \\
& Bachelor and masters & 96 & 48.00 \\
Occupational Status & $<6$ years & 59 & 29.50 \\
\multirow{2}{*}{ Employee Performance } & With side job & 141 & 70.50 \\
& No side job & 89 & 44.50 \\
& Poor & 111 & 55.50 \\
& Good & 73 & 36.50 \\
\hline
\end{tabular}

Study subjects with the highest education level of high school and diploma three were 104 people (52.00\%) and 96 people (48.00\%) had the last undergraduate and postgraduate level of education. Study subjects whose work period was $\geq 6$ years were 141 people (70.50\%) and 59 people $(29.50 \%)$ who worked for $<6$ years. Most of them do not have additional work, as many as 111 people (55.50\%) and those who have additional work are 89 people (44.50\%).

\section{Bivariate Analysis}

Table 4 shows the bivariate analysis with the results of work stress, leadership style, level of education, tenure, and type of work, have a positive relationship with employee performance. The relationship between mild work stress and good employee performance was 91 study subjects (79.13\%) and severe work stress with poor performance as many as 49 study subjects (57.65\%).

Study subjects with mild work stress were 0.19 times more likely to perform better than study subjects with severe work stress and it was statistically significant $(\mathrm{OR}=0.19$; $\mathrm{p}<0.001$ ).

Study subjects with a democratic leadership style on their leaders are 4.95 times 
Handayani et al./ Ecological effect of community health center on the work performance

more likely to perform better than those with an authoritarian leadership style $(\mathrm{OR}=4.95$; $\mathrm{p}=0.002)$.

Study subjects with undergraduate/ postgraduate education levels were 2.94 times more likely to perform better than those with education Diploma III $(\mathrm{OR}=2.94$; $\mathrm{p}=$ 0.001). Study subjects with tenure $\geq 6$ years had 3.56 times likelihood to perform better than those with tenure $<6$ years $(\mathrm{OR}=$ 3.56; $\mathrm{p}=0.001$ ).

Study subjects without additional work were 3.33 times more likely to perform better than study subjects who received additional work and it was statistically significant $(\mathrm{OR}=$ $3.33 ; \mathrm{p}<0.001)$.

Table 4 Bivariate analysis of the effects of work stress, leadership style, level of education, years of service and type of work on employee performance

\begin{tabular}{|c|c|c|c|c|c|c|c|c|}
\hline \multirow{3}{*}{$\begin{array}{l}\text { Independent } \\
\text { Variable }\end{array}$} & \multicolumn{4}{|c|}{ Employee Performance } & \multirow{2}{*}{\multicolumn{2}{|c|}{ Total }} & \multirow{3}{*}{$\mathbf{O R}$} & \multirow{3}{*}{$\mathbf{p}$} \\
\hline & \multicolumn{2}{|c|}{ Poor } & \multicolumn{2}{|c|}{ Good } & & & & \\
\hline & $\mathbf{N}$ & $\%$ & $\mathbf{N}$ & $\%$ & $\mathbf{N}$ & $\%$ & & \\
\hline \multicolumn{9}{|l|}{ Work Stress } \\
\hline Mild & 24 & 20.87 & 91 & 79.13 & 115 & 100 & \multirow[t]{2}{*}{0.19} & \multirow[t]{2}{*}{$<0.001$} \\
\hline Severe & 49 & 57.65 & 36 & 42.35 & 85 & 100 & & \\
\hline \multicolumn{9}{|l|}{ Leadership Style } \\
\hline Authoritarian & 40 & 61.54 & 25 & 38.46 & 65 & 100 & \multirow[t]{2}{*}{4.95} & \multirow[t]{2}{*}{0.002} \\
\hline Democratic & 33 & 24.44 & 102 & 75.56 & 135 & 100 & & \\
\hline \multicolumn{9}{|l|}{ Education } \\
\hline SHS, DIII & 50 & 48.08 & 54 & 51.92 & 104 & 100 & \multirow[t]{2}{*}{2.94} & \multirow[t]{2}{*}{0.001} \\
\hline Bachelor, Master & 23 & 23.96 & 73 & 76.04 & 96 & 100 & & \\
\hline \multicolumn{9}{|l|}{ Tenure } \\
\hline$<6$ years & 34 & 57.63 & 25 & 42.37 & 59 & 100 & \multirow[t]{2}{*}{$3 \cdot 56$} & \multirow[t]{2}{*}{0.001} \\
\hline$\geq 6$ years & 39 & 27.66 & 102 & 72.34 & 141 & 100 & & \\
\hline \multicolumn{9}{|l|}{ Type of Job } \\
\hline With side job & 46 & 51.69 & 43 & 48.31 & 89 & 100 & \multirow[t]{2}{*}{$3 \cdot 33$} & \multirow[t]{2}{*}{$<0.001$} \\
\hline No side job & 27 & $24 \cdot 32$ & 84 & 75.68 & 111 & 100 & & \\
\hline
\end{tabular}

\section{Multivariate Analysis}

Employees with heavy work stress had a possibility (logodd) to perform well 1.65 units lower than mild stress $(b=-1.65 ; 95 \% \mathrm{CI}=-$ 2.58 to $-0.72 ; \mathrm{p}=0.001$ ).

Employees with a democratic leadership style have the possibility (logodd) to perform well 1.40 units greater than the authoritarian leadership style $(b=1.40 ; 95 \%$ $\mathrm{CI}=0.44$ to $2.36 ; \mathrm{p}=0.004$ ).

Employees with an undergraduate / graduate level of education have a (logodd) good performance 1.58 units greater than employees with a high school / diploma III level of education ( $b=1.58 ; 95 \% \mathrm{CI}=0.65$ to 2.52; $\mathrm{p}=0.001$ ).

Employees with a work period of $\geq 6$ years have the possibility (logodd) to perform well 1.72 units greater than the tenure of $<6$ years $(\mathrm{b}=1.72 ; 95 \% \mathrm{CI}=0.73$ to $2.70 ; \mathrm{p}=$ o.001).

Employees who do not have additional work have the possibility (logodd) to perform better at 2.05 units than employees with additional work $(\mathrm{b}=2.05 ; 95 \% \mathrm{CI}=1.07$ to 3.03; $\mathrm{p}<0.001)$. 
Handayani et al./ Ecological effect of community health center on the work performance

Table 5 Multilevel logistic regression analysis on the influence of public health center, work stress and leadership style on the performance of health workers

\begin{tabular}{|c|c|c|c|c|}
\hline \multirow{2}{*}{ Independent variables } & \multirow{2}{*}{ b } & \multicolumn{2}{|c|}{$95 \% \mathrm{CI}$} & \multirow[b]{2}{*}{$\mathbf{p}$} \\
\hline & & Lower limit & Upper limit & \\
\hline \multicolumn{5}{|l|}{ Fixed Effect } \\
\hline Work Stress (good) & -1.65 & -2.58 & -0.72 & 0.001 \\
\hline Leadership Style (democratic) & 1.40 & 0.44 & 2.36 & 0.004 \\
\hline Education ( $\geq$ bachelor) & 1.58 & 0.65 & 2.52 & 0.001 \\
\hline Tenure ( $\geq 6$ years) & 1.72 & 0.73 & 2.70 & 0.001 \\
\hline Occupational status (no side job) & 2.05 & 1.07 & 3.03 & $<0.001$ \\
\hline Constanta & -2.45 & -3.86 & -1.04 & 0.001 \\
\hline \multicolumn{5}{|l|}{ Random Effect } \\
\hline \multicolumn{5}{|l|}{ Public Health Center } \\
\hline Var (constanta) & 0.48 & 0.06 & 3.72 & \\
\hline $\mathrm{n}$ observation $=\mathbf{2 0 0}$ & & & & \\
\hline Log likelihood= -87.36 & & & & \\
\hline LR test vs. logistic regression, $\mathrm{P}=0.09$ & & & & \\
\hline $\mathrm{ICC}=12.74 \%$ & & & & \\
\hline
\end{tabular}

\section{DISCUSSION}

\section{The effect of work stress on work performance}

The results of this study indicate that there is a negative influence of work stress on employee performance at the public health center $(b=-1.65 ; 95 \% \mathrm{CI}=-2.58$ to $-0.72 ; \mathrm{p}=0.001)$. Employees with heavy work stress have the possibility (logodd) to perform well -1.65 units lower than employees with mild work stress and are statistically significant.

This is in line with Gharib et al. (2016), on 102 academic staff who showed that moderate or low levels of work stress showed good or increased performance. Job stress is one of the occupational diseases for workers and can affect individuals physically and psychologically which can cause pressure on the individual so that it impacts on employee performance. Stress has a positive effect to some extent that employees can overcome it, if it exceeds the limits of his ability he can have a negative impact on employees (Ahmed and Ramzan, 2013). Support from a leader for employees in completing a job also has an important role, where the lack of support can increase high job stress and have an impact on dissatisfaction in employee performance (Murali et al., 2017).

\section{The effect of leadership style on work performance}

The results showed a positive influence between leadership style on employee performance at the public health center $(\mathrm{b}=$ 1.40; $95 \% \mathrm{CI}=0.44$ to 2.36 ; $\mathrm{p}=0.004$ ). Employees with democratic leadership perceptions have the possibility (logodd) to perform well 1.40 units greater than authoritarian leadership perception.

This is in line with Fitria et al. (2018), which shows that there is a significant relationship between leadership and the performance of public health center employees. Basically, a leader has an important role in influencing one's performance. Leadership has an important role in the sustainability of an organization, where good leadership leads to better performance and achievement of goals. Poor performance can be caused by one factor that is the leadership style of unsuccessful leaders (Shah et al., 2016).

The democratic leadership style also known as the participative leadership style encourages its employees to participate in the decision making process in the organization. A democratic leadership style enables an organization to get the full benefit when implementing it in its organization where 
Handayani et al./ Ecological effect of community health center on the work performance

management excellence is better employee performance (NawoseIng'ollan and Roussel, 2017).

\section{Effect of education on work per- formance}

The results of this study indicate that there is a positive influence on the level of education on employee performance at the public health center $(b=1.58 ; 95 \% \mathrm{CI}=0.65$ to 2.52 ; $\mathrm{p}=$ 0.001). Employees with an undergraduate / graduate level have a (logodd) good performance 1.58 units greater than employees with diploma III level. This is in line with Miranti et al. (2016), which states that the variable level of education has a significant influence on employee performance. With the increase in the level of education of its employees, it will also be followed by a significant increase in employee performance. Kiram (2014) states that some stressors experienced by public health center employees are work incompatibility with employee education. With inappropriate education with the program it is his responsibility to cause the work carried out is not optimal.

Education is an attempt by a person or group of people to grow up or reach a level of life or obtain a higher income. Employee performance is influenced by the level of education where higher education is able to produce a quality workforce and have a progressive mindset (Juliani, 2017). According to Abdulrahamon et al. (2018), shows that education significantly influences employee performance. Employees with higher educational qualifications show better job performance. The relationship between education level and performance in addition to positively influencing the performance of core tasks, education level is also related to increasing employee creativity (Hassan and Ogunkoya, 2014).

\section{Effect of tenure on work perform-} ance

The results of this study indicate that there is a positive effect on the length of service of employees on the performance of employees at the health center $(b=1.72 ; 95 \% \mathrm{CI}=0.73$ to $2.70 ; \mathrm{p}=0.001)$. Employees with a service period of $\geq 6$ years have a possibility (logodd) to perform well 1.72 units greater than employees with tenure $<6$ years and are statistically significant.

According to the Miranti et al. (2016), shows that tenure has a positive influence on employee performance. With an increase in work tenure, it will also be followed by a significant increase in work productivity. Employees who have experience in the workplace are more accustomed to those who are younger, non-experience or fresh graduates. Employees are accustomed to work pressure, work culture and work ethics applied in the workplace.

\section{Effect of Job Type on Employee Performance}

The results of this study indicate that there is a positive influence on the work type of employees on employee performance in health centers $(b=2.05 ; 95 \% \mathrm{CI}=1.07$ to 3.03 ; $\mathrm{p}<0.001)$. Employees without additional work have the possibility (logodd) to perform better at 2.05 units than employees with additional work and the effect is statistically significant.

According to Widianti (2018), there are still employees at the public health center who are placed not in accordance with their main tasks and functions. According to Rajan (2018), the existence of additional types of work delegated to employees outside their core duties resulted in excessive workload. High workload has an impact on employee health and if it lasts longer can affect employee performance. Weight loss, fatigue, and stress are effects that are often felt. The workload in addition to influencing health also affects the behavior, job satisfaction, commitment, family relationships, and social life of its employees. Another opinion in Kiram (2014), states that some employees at 
Handayani et al./ Ecological effect of community health center on the work performance

the public health center feel that there is a lack of workforce which causes more work to be done which makes the workload of each employee heavier.

\section{AUTHOR CONTRIBUTION}

Nia Handayani conducted all stages of the study and wrote the paper. Didik Gunawan Tamtomo was instrumental in developing ideas, study designs, and hypotheses. Bhisma Murti has a role in preparing the study framework, processing data analysis, representing the results.

\section{CONFLICT OF INTEREST}

There was no conflict of interest.

\section{FUNDING AND SPONSORSHIP}

This study was self-funded.

\section{ACKNOWLEDGEIMENT}

Our gratitude goes to the Health Service and Public health center in Klaten Regency for allowing this study to be carried out and for employees at the Klaten District Health Center, who are willing to be the study subject.

\section{REFERENCE}

Abdulrahamon A, Toyin AS, Adeola F (2018). Impact of educational, professional qualification and years of experience on accountant job performance. J account finance manag, 4(1): 32-44. Retrieved from www.iiardpub.org

Ahmed A, Ramzan M (2013). Effects of job stress on employees job performance a study on banking sector of Pakistan. IOSR Journal of Business and Management, 11(6): 61-68. https://doi.org/$10.9790 / 487 x-1166168$

Amir, Tamsah H, Kadir I (2018). Pengaruh kepemimpinan, kompensasi, dan kedisiplinan terhadap kinerja tenaga magang di Public health center Mangkoso Kabupaten Barru (The influence of leadership, compensation, and discipline on the performance of apprentices in Mangkoso Health Center in Barru Regency). J Manag. 1(3): 84-106. Retrieved from https://journal.stieamkop.ac.id/index.php/yume.

Bhui K, Dinos S, Galant-Miecznikowska M, de Jongh B, Stansfeld S (2016). Perceptions of work stress causes and effective interventions in employees working in public, private and non-governmental organisations: A qualitative study. B J Psych Bulletin, 40(6): 318-325. https://doi.org/10.1192/pb.bp.115.050823.

Busro, Muhammad (2018). Teori-teori manajemen sumber daya manusia (Theories of human resource management). Jakarta: Prenadamedia

Fitria NR, Arso SP, Kusumawati A (2018). Hubungan variabel organisasi dan psikologis dengan kinerja pegawai public health center bendan kota pekalongan dalam era jaminan kesehatan nasional (Relationship between organizational and psychological variables with the performance of employees of the Pekalongan city health center in the era of national health insurance). Jurnal Kesehatan Masyarakat. 6(5). http://ejournal3.undip.ac.id/index.php/jkm

Gharib MN, Jamil SA, Ahmad M, Ghouse S (2016). The impact of job stress on job performance: A case study on academic staff at Dhofar University. Int J eco res, 13 (1): 21-33. https://www.researchgate.net/publication/

Hassan B, Ogunkoya O (2014). Demographic variables and job performance: any link?. J Econ 10 (4): 19-30. http://journals.univ-danubius.ro/index.php/oeconomica/article/view/2420/2666

Juliani T (2017). Analysis of incentive, work discipline, and education levels that influence employee performance. J Appl Manag, 15 (2): 355-361. http://- 
Handayani et al./ Ecological effect of community health center on the work performance

dx.doi.org/10.18202/jam23026332.-

15.2 .20

Kiram S (2014). Stres dan manajemen stres pada pegawai public health center (Stress and stress management in public health center employees). Skripsi Fakultas Ilmu Sosial dan Politik Universitas Indonesia, Depok.

Li L, Ai H, Gao L, Zhou H, Liu X, Zhang Z, Sun T, Fan L (2017). Moderating effects of coping on work stress and job performance for nurses in tertiary hospitals: A cross-sectional survey in China. BMC Health Serv Res, 17(1):1-8. https://doi.org/10.1186/s129130173483 .

Mawaranti R, Prasetio AP (2018). Dampak stres kerja terhadap kepuasan kerja pada pegawai UPT Public health center Jasinga (The impact of job stress on job satisfaction on Jasinga Public health center staff). Jurnal Riset Bisnis dan Manajemen, 13 (1): 37-45. http://ejournalfb.ukdw.ac.id/index.php/jrmb/article/view/302

Miranti E, Herkulana, Yacoub Y (2016). Pengaruh tingkat pendidikan, masa kerja dan motivasi kerja terhadap kinerja karyawan (The effect of education level, years of service and work motivation on employee performance). Jurnal Pendidikan dan Pembelajaran Khatulistiwa, 5 (3). http://jurnal.untan.ac.id/index.php/pdpb/article/view/14462

Murali S, Basit A, Hassan Z (2017). Impact of job stress on employee performance. J account bus manag, 5: 15-33. https://doi.org/10.24924/ijabm/2017.11/v5.iss2/13.33

Musinguzi C, Namale L, Rutebemberwa E, Dahal A, Nahirya-Ntege P, Kekitiinwa A (2018). The relationship between leadership style and health worker motivation, job satisfaction and teamwork in Uganda. J Healthc Leadersh,10: 21-
32. https://doi.org/10.2147/jhl.s147885 .

Nawoseing'ollan D, Roussel J (2017). Influence of leadership styles on employees' performance: a study of Turkana County, Kenya. Int j bus soc sci res, 8(7): 82-98. Retrieved from www.ijbssnet.com.

Peraturan Menteri Kesehatan Nomor 75 Tahun 2014 tentang Pusat Kesehatan Masyarakat

Rajan D (2018). Negative impacts of heavy workload: a comparative study among sanitary workers. Int J Sociol, 2(6). https://doi.org/10.15406/sij.2018.02.ooo86

Samsuddin H (2018). Kinerja karyawan: tinjauan dari gaya kepemimpinan, budaya organisasi dan komitmen organisasi (Employee performance: an overview of leadership styles, organizational culture and organizational commitment). Sidoarjo: Indomedia Pustaka

Shah SMM, Hamid K, Shaikh UA, Qureshi MA, Pahi MH (2016). The relationship between leadership styles and job performance: the role of work engagement as a mediator : review article. 02(10): 242-253. https://edupediapublications.org/journals

Shivendra D, Kumar MM (2016). A study of job satisfaction and job stress among physical education teachers working in government, semigovernment and private schools. J sports sci fit, 6(1): 8999. Retrieved from http://spot.lib.auburn.edu/

Wahyudi (2017). Manajemen konflik dan stres dalam organisasi (Conflict and stress management in organizations). Bandung: Alfabeta/

Widianti RS, Noor M, Linggi RK (2018). Kinerja pegawai public health center dalam pelayanan kesehatan di Kecamatan Sangatta Selatan Kabupaten 
Handayani et al./ Ecological effect of community health center on the work performance

Kutai Timur (Performance of public health center employees in health services in the District of Sangatta Selatan,
Kutai Timur District). eJournal Ilmu Pemerintahan 6(1): 185-198. https://ejournal.ip.fisip-unmul.-ac.id 